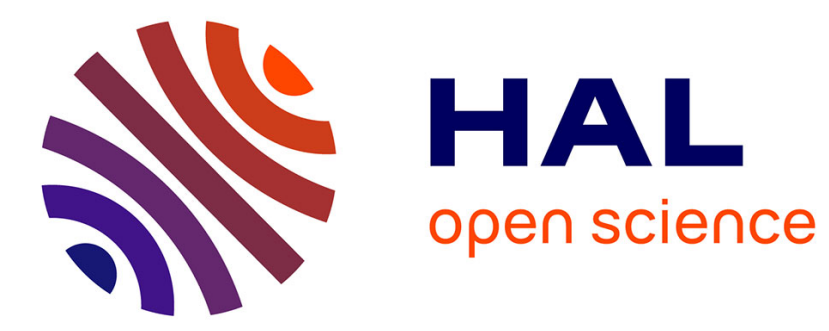

\title{
Porous microspheres of manganese-cerium mixed oxides by a polyvinylpyrrolidone assisted solvothermal method
}

\author{
F. Schmit, L. Bois, R. Chiriac, F. Toche, F. Chassagneux, C. Descorme, M.
} Besson, L. Khrouz

\section{- To cite this version:}

F. Schmit, L. Bois, R. Chiriac, F. Toche, F. Chassagneux, et al.. Porous microspheres of manganesecerium mixed oxides by a polyvinylpyrrolidone assisted solvothermal method. Journal of Physics and Chemistry of Solids, 2017, 103, pp.22-32. 10.1016/j.jpcs.2016.11.025 hal-01502102

\section{HAL Id: hal-01502102 \\ https://hal.science/hal-01502102}

Submitted on 13 Apr 2021

HAL is a multi-disciplinary open access archive for the deposit and dissemination of scientific research documents, whether they are published or not. The documents may come from teaching and research institutions in France or abroad, or from public or private research centers.
L'archive ouverte pluridisciplinaire HAL, est destinée au dépôt et à la diffusion de documents scientifiques de niveau recherche, publiés ou non, émanant des établissements d'enseignement et de recherche français ou étrangers, des laboratoires publics ou privés. 


\title{
Porous microspheres of manganese-cerium mixed oxides by a polyvinylpyrrolidone assisted
} solvothermal method.

F. Schmit ${ }^{1,2}$, L. Bois ${ }^{1,}$, R. Chiriac ${ }^{1}$, F. Toche ${ }^{1}$, F. Chassagneux ${ }^{1}$

C. Descorme ${ }^{2}$, M. Besson ${ }^{2}$

L. Khrouz ${ }^{3}$

1 Laboratoire des Multimatériaux et Interfaces, UMR 5615, CNRS/ Université Claude Bernard - Lyon 1, 43 Bd 11 novembre 1918, 69622 Villeurbanne, France.

2 IRCELYON, Institut de Recherches sur la catalyse et l'environnement de Lyon, UMR 5256 CNRS/ Université Claude Bernard - Lyon 1, 2, av. A. Einstein, 69622, Villeurbanne, France

3 ENS LYON Laboratoire de Chimie (LR6, site Monod), 46, allée d'Italie, 69364 Lyon cedex 07, France.

*corresponding author : Laurence Bois, laurence.bois@univ-lyon1.fr

\begin{abstract}
Mixed cerium manganese oxides were synthesized using a polyvinylpyrrolidone (PVP) assisted solvothermal method. Materials obtained after calcination at $400^{\circ} \mathrm{C}$ were characterized by Xray diffraction, scanning and transmission electron microscopies, electron paramagnetic resonance (EPR), Raman spectroscopy, thermal analysis and nitrogen adsorption/desorption isotherms. The influence of the synthesis parameters on the oxide structure, such as the Mn:Ce ratio or the amount of PVP, was discussed. Micrometric spheres of mixed Mn-Ce oxides, resulting from the aggregation of $100 \mathrm{~nm}$ porous snowflakes, were successfully synthesized. These snowflakes were formed from the aggregation of smaller oriented crystallites (size $4 \mathrm{~nm}$ ). The hydrothermal stability of these materials was also investigated.
\end{abstract}

Key words: Crystallites, Segregation, Hydrothermal crystal growth, Nanomaterials, Oxides. 


\section{Introduction}

$\mathrm{MnO}_{\mathrm{x}}-\mathrm{CeO}_{2}$ materials have been reported as highly active catalysts in many different oxidation reactions [1]. It is thought important to develop some new methods to synthesize $\mathrm{MnO}_{\mathrm{x}}-\mathrm{CeO}_{2}$ materials with a controlled morphology. In cerium oxide, cerium may easily switch between the III and IV oxidation states and might be substituted with lower valence elements, inducing the creation of oxygen vacancies. Cerium oxide is also known to release oxygen at high temperature. $\mathrm{CeO}_{2}$ is used as fast ion conductor, oxygen storage capacitor, catalyst and electrolyte for solid oxide fuel cells [2-3]. Nano-structured ceria synthesis has been recently reviewed $[3,4]$. By changing the temperature and the $\mathrm{NaOH}$ concentration or by using organic additives which ones adsorb onto the surface of the growing particles, different morphologies of ceria could be obtained [5-8]. For example, the use of polyvinylpyrrolidone (PVP) as a capping ligand has been reported to allow the formation of monodisperse spherical ceria particles with size in the range 100-500 nm [9-19]. Manganese oxides with different $\mathrm{Mn}$ valencies, are also well known in oxidation catalysis and as natural oxidants [20]. A lot of research is devoted to the elaboration of nano-structured manganese oxides-based catalysts for the oxidation of volatile organic compounds [21], the selective reduction of $\mathrm{NO}$ with $\mathrm{NH}_{3}$ [22] or the oxidation of water [23]. The combination between manganese and cerium oxides has been the subject of several studies, mostly in oxidation catalysis [1,24-32], but also for the selective reduction of NO by $\mathrm{NH}_{3}[33,34]$. A synergetic effect is often reported between manganese and cerium. Manganese is known to easily substitute cerium in the ceria lattice, increasing the oxygen mobility in ceria. The enhancement of the catalyst efficiency is then explained by the improvement of the oxygen activation and transfer through redox cycles involving both manganese and cerium. The reduced manganese oxide is re-oxidized by ceria and the reduced cerium oxide is re-oxidized to $\mathrm{CeO}_{2}$ by the oxygen from the air [27]. Structural characterization studies have been realized [35-37]. Recently, theoretical studies are gain more and more interest to explain the behaviour of such mixed oxides [38-41]. Ce-Mn oxides are also used to benefit from their specific electrical properties, such as in solid oxide fuel cells [42-44]. Ce-Mn oxides can be synthesized by impregnation, coprecipitation, sol-gel process, hydrothermal, or glycothermal and combustion methods [27]. Usually, a complex mixture is formed containing both a solid solution and separated manganese oxides phases. Only a few studies concerned the synthesis of mixed manganese-cerium systems via solvothermal methods, generally allowing a better morphology control, as cubes, rods or flowers, using either $\mathrm{pH}$ control or acrylic acid 
adding $[24,25]$. In this paper, we describe the synthesis of porous microspheres of manganese-cerium mixed oxides using a solvothermal method and PVP, as a capping ligand. Three different Mn:Ce ratios were considered with an increasing amount of PVP. The final calcined products were studied by X-ray diffraction, SEM, TEM, EPR, Raman spectroscopy, TGA and nitrogen adsorption desorption.

\section{Experimental Section}

\subsection{Synthesis of the materials.}

$\mathrm{Ce}\left(\mathrm{NO}_{3}\right)_{3} \cdot 6 \mathrm{H}_{2} \mathrm{O}(5 \mathrm{mmol}, 2,17 \mathrm{~g})$ was mixed in ethanol $(30 \mathrm{~mL})$ and water $(10 \mathrm{~mL})$ with $1 \mathrm{~g}(9$ mmol) or $3 \mathrm{~g}(27 \mathrm{mmol})$ of PVP (MW 40000). The manganese salt $\mathrm{Mn}\left(\mathrm{NO}_{3}\right)_{2}, 4 \mathrm{H}_{2} \mathrm{O}$ was added in various proportion. The $\mathrm{Mn}: \mathrm{Ce}$ ratio was fixed at $0,0.25,0.5$, or 1 . The solvothermal treatment was done in a $250 \mathrm{~mL}$ Teflon-lined autoclave, at $200^{\circ} \mathrm{C}\left(10^{\circ} \mathrm{C} / \mathrm{min}\right)$, for $48 \mathrm{~h}$. The solid was separated by filtration and washed three times with water, before to be dried at $70^{\circ} \mathrm{C}$. A brown powder was obtained whenever manganese nitrate was used. Finally, a thermal treatment under air was realized at $400^{\circ} \mathrm{C}$ at $1^{\circ} \mathrm{C} /$ min during $5 \mathrm{~h}$ to eliminate the polymer.

The hydrothermal stability was tested upon treatment at $200^{\circ} \mathrm{C}$ during $24 \mathrm{~h} .80 \mathrm{mg}$ of sample was introduced in a $250 \mathrm{~mL}$ Teflon-lined autoclave containing $100 \mathrm{~mL}$ of water. Black powders were obtained after the hydrothermal treatment. Samples were named as $\mathrm{CM}_{\mathrm{x}} \mathrm{P}_{\mathrm{y}}$ where $\mathrm{x}=\mathrm{Mn}: \mathrm{Ce}$ ratio and $y=$ polymer weight $(y=0,1$ or $3 g)$. Finally, if the sample was hydrothermally treated, an $h$ was introduced at the end of the sample name $\left(\mathrm{CM}_{x} \mathrm{P}_{\mathrm{y}}-\mathrm{h}\right)$.

\subsection{Characterization methods}

X-ray diffraction (XRD) patterns were recorded on a PANalytical Xpert Pro diffractometer (The Netherlands) equipped with a monochromator, using $\mathrm{Cu} \mathrm{K \alpha}$ radiation (wavelength of $1.54 \AA$ ). The width of the (220) reflection of ceria was used to calculate the crystallite size because there was no oxide manganese reflexion in this zone. SEM pictures were acquired on a S800 Hitachi microscope operating at $15 \mathrm{kV}$ in the "Centre Technologiques des Microstructures de l'Université de Lyon", after gold/palladium metallization. TEM pictures were acquired on a Topcon instrument operating at $200 \mathrm{kV}$ in the "Institut Lumière Matière, University Lyon 1". Prior observations, the samples were ground and deposited directly on a copper grid coated with a holey carbon film. EPR measurements on selected samples were carried out using a X-band spectrometer (Bruker EMX plus, double mode) and a X-band 
(9.4 GHz) Bruker ESP 500E spectrometer using a standard rectangular cavity. Simulations of the spectra were realized using easyspin (Matlab toolbox). The experimental spectra were simulated using the following parameters: frequency $=9.389 \mathrm{GHz}$; temperature $=25 \mathrm{~K}$; microwave power $=21 \mathrm{~mW}$; amplitude modulation $=3 \mathrm{G}$; and modulation frequency $=100.00 \mathrm{kHz}$. Raman spectra were acquired on a Renishaw RM 1000 microspectrometer at $\lambda=532 \mathrm{~nm}$ (CECOMO, University Lyon I). Thermogravimetric analyses of the calcined samples were realized with a TGA/SDTA 851 Mettler Toledo apparatus. $20 \mathrm{mg}$ of sample were placed in the platinum crucible. Air was used as the reactive gas $\left(50 \mathrm{~mL} \cdot \mathrm{min}^{-1}\right)$. All samples were heated at $20^{\circ} \mathrm{C} \cdot \mathrm{min}^{-1}$ from 30 to $1200^{\circ} \mathrm{C}$. First derivative curve was used to calculate the different mass loss steps, while the SDTA curve (differential thermal analysis) provided information about the thermal phenomena occurring upon the sample heating. Textural characterizations were realized using nitrogen adsorption/desorption isotherms on a BelsorpMini (Bel Instruments, Japan). Prior analysis, samples were outgassed under vacuum $\left(100^{\circ} \mathrm{C}\right.$ for $4 \mathrm{~h}$ ). The pore size distribution (max radius) and the mesoporous volume were calculated from the desorption branch of the isotherms using the Barrett-Joyner-Halenda (BJH) method. The total porous volume was measured at $P / P_{0}=0.98$. The surface area was determined by the Brunauer-EmmettTeller (BET) approach.

\section{Results}

\subsection{After the solvothermal treatment.}

At the end of solvothermal treatment, the polymer capping the inorganic phase is evidenced by TEM (Fig. 1a \& b). The departure of the polymer was followed using TGA/SDTA analysis (Fig. 2). A weight loss of $13.1 \%$ was measured at $250^{\circ} \mathrm{C}$ (Fig. 2a), associated to an exothermic peak (Fig. 2b), due to the polymer oxidation process. The weight loss measured, has allowed an estimation of the amount of PVP around the oxide at the end of the solvothermal process. It is found the 0.25 PVP unit for one cerium was present. All the following analysis have been done on samples thermally treated at $400^{\circ} \mathrm{C}$, in which the polymer has been eliminated.

\subsection{XRD results}

The X-ray diffraction patterns of the $\mathrm{CM}_{\mathrm{x}} \mathrm{P}_{\mathrm{y}}$ samples are given in Figure 3. The influence of the $\mathrm{Mn}: \mathrm{Ce}$ ratio on the ceria structure is shown in Figure 3a. In fact, a typical well-crystallized ceria pattern with a cubic fluorite structure was obtained when no manganese was added $\left(\mathrm{CM}_{0} \mathrm{P}_{3}\right)$. The width of the half 
maximum height of the $(220)$ reflection at $47.5^{\circ}$ was equal to $0.58^{\circ}$, corresponding to a crystallite size of $16 \mathrm{~nm}$. Upon addition of manganese, $\mathrm{CM}_{0.25} \mathrm{P}_{3}$ and $\mathrm{CM}_{0.5} \mathrm{P}_{3}$ patterns revealed a less crystallized ceria, with a shift of the (220) reflection to higher angles, from $47.5^{\circ}$ to $47.8^{\circ}$. The shift of the (111) reflection is also seen in the insert Fig. 3a. The width of the (220) reflection, $1.61^{\circ}$ and $2.24^{\circ}$, respectively indicated a 5.8 and $3.9 \mathrm{~nm}$ crystallite size. The hausmannite phase $\mathrm{Mn}_{3} \mathrm{O}_{4}$ could be detected in the $\mathrm{CM}_{0.5} \mathrm{P}_{3}$ sample from the (202) reflection at $36.2^{\circ}$ (ICDD $\mathrm{n}^{\circ}$ 89-4837). For the highest $\mathrm{Mn}:$ Ce ratio (1), the ceria phase looked the same as in the $\mathrm{CM}_{0.5} \mathrm{P}_{3}$ sample, while the hausmannite reflections became more intense. The width of the (220) ceria reflection was found constant $\left(2.20^{\circ}\right)$. In the reference sample, $\mathrm{MP}_{3}$, prepared without cerium, a well-crystallized hausmannite phase was obtained. The shift of the ceria reflection revealed that part of the manganese ions was inserted inside the ceria structure. Such decrease of the cell parameter of ceria upon insertion of the manganese has already been reported $[45,47]$. In fact, a Rietveld analysis has recently confirmed that when $\mathrm{Mn}^{2+}$ (ionic radius $0.67 \AA$ ) substitutes cerium in ceria $\left(\mathrm{Ce}^{4+}\right.$, ionic radius $0.92 \AA$ ), a decrease of the cell parameter occurs, as well as a decrease of the crystallite size [47]. The solubility of $\mathrm{Mn}^{2+}$ inside the ceria lattice (at $1300^{\circ} \mathrm{C}$ ) has been estimated between 5 and $10 \mathrm{~mol} \%$ [44]. The smaller $\mathrm{Mn}^{4+}$ cation $\left(\mathrm{Mn}^{4+}\right.$, ionic radius $0.53 \AA$ ) is also expected to be easily inserted inside the ceria [48]. Figure 3b shows the influence of the proportion of polymer on the ceria structure for the $\mathrm{CM}_{0.5} \mathrm{P}_{\mathrm{x}}$ samples. The crystallinity of the ceria (crystallite size $=6.8 \mathrm{~nm}$ ) and hausmannite phases were found to be a little higher in the $\mathrm{CM}_{0.5} \mathrm{P}_{0}$ pattern compared to the $\mathrm{CM}_{0.5} \mathrm{P}_{1}$ (crystallite size $=5.5 \mathrm{~nm}$ ) and $\mathrm{CM}_{0.5} \mathrm{P}_{3}$ samples (crystallite size=3.9 nm). Moreover, in the $\mathrm{CM}_{0.5} \mathrm{P}_{3}$ sample, a slight shift of the (111) reflection towards to higher angles was observed, indicating that the degree of substitution of manganese inside ceria was higher at higher polymer ratio. By increasing the amount of polymer, the substitution of manganese into the ceria lattice (i.e. solid solution) was favoured and the $\mathrm{Mn}_{3} \mathrm{O}_{4}$ crystallization was prevented. Indeed PVP acts as ligand and form complexes with metal ions through its amide groups. PVP covers the small nanocrystals ceria seeds and limit the crystal growth [2]. Manganese ions diffusion inside the ceria seeds is favored by the presence of PVP. This explains why manganese-cerium solid solution formation is favored and crystallization prevented.

\subsection{SEM and TEM results}


The amount of polymer also influenced the crystallites morphology. The SEM pictures for $\mathrm{CM}_{0.5} \mathrm{P}_{0}$ (Fig.4a) and $\mathrm{CM}_{0.5} \mathrm{P}_{1}$ (Fig.4b) revealed the important agglomeration of micrometric grains, while large micrometric spheres with a hole were only obtained in the case of the $\mathrm{CM}_{0.5} \mathrm{P}_{3}$ sample (Fig.4c). The Mn:Ce ratio also strongly influenced the morphology. In fact, submicronic spheres were observed in the samples with the lower Mn:Ce ratios: 0 (Fig.4d) or 0.25 (Fig.4e); while large micrometric spheres with a hole, were obtained only in the $\mathrm{CM}_{0.5} \mathrm{P}_{3}$ sample (Fig.4c). Moreover, in the sample, obtained without any cerium $\left(\mathrm{MP}_{3}\right)$, the hausmannite $\mathrm{Mn}_{3} \mathrm{O}_{4}$ phase exhibited a flower-like morphology of about 2 microns in size (Fig.4f). Submicronic spherical morphologies of ceria were already noted in the assisted PVP hydrothermal synthesis of ceria [14,17,18,49,51]. Indeed, PVP seems to easily deposit on the surface on the ceria seeds and stabilize the nanosphere morphology [2].

TEM pictures showed that in the absence of manganese $\left(\mathrm{CM}_{0} \mathrm{P}_{3}\right.$ sample), regular $300 \mathrm{~nm}$ spheres were obtained (Fig. 5a). For a $\mathrm{Mn}: \mathrm{Ce}$ ratio of 0.25 , similar spherical aggregates were observed (Fig. 5b), but with a lower size in the range 100-200 nm. At higher manganese ratio, $\left(\mathrm{CM}_{0.5} \mathrm{P}_{3}\right.$ sample) (Fig. $\left.5 \mathrm{c}\right)$, the spherical aggregates usually showed a diameter below $100 \mathrm{~nm}$ and looked like snowflakes, exhibiting a porous structure. At a larger scale, these $100 \mathrm{~nm}$ spherical type particles were aggregated into large micrometric spheres, as observed by SEM. For a Mn:Ce ratio of 1, snowflake's like spheres were also observed (Fig. 5d). Without PVP (Fig. 5e), the snowflake morphology is not found as seen in the picture of the $\mathrm{CM}_{0.5} \mathrm{P}_{0}$ sample. Using a lower amount of PVP (sample $\mathrm{CM}_{0.5} \mathrm{P}_{1}$ shown in Fig. $5 \mathrm{f}$ ), a snowflake morphology is obtained, but their size is less well defined.

The HRTEM images revealed that the ceria spheres in $\mathrm{CM}_{0} \mathrm{P}_{3}$ (Fig. 6b) consisted of aggregates of smaller crystallites of ceria, of rectangular ones $(15 \times 30 \mathrm{~nm})$. For a Mn:Ce ratio of 0.25 $\left(\mathrm{CM}_{0.25} \mathrm{P}_{3}\right)$, the spherical aggregates (Fig. 6e) was formed with even smaller crystallites $(7 \mathrm{~nm})$. In the presence of a higher manganese ratio $\left(\mathrm{CM}_{0.5} \mathrm{P}_{3}\right.$ sample) (Fig. 6h), the aggregates were constituted of the smallest ceria crystallites $(3 \mathrm{~nm})$. Electron diffraction patterns revealed a very clear preferential orientation of the ceria crystallites, in the $\mathrm{CM}_{0} \mathrm{P}_{3}$ and $\mathrm{CM}_{0.25} \mathrm{P}_{3}$ samples (Fig. $6 \mathrm{c}$ and 6f). The preferential orientation of each ceria aggregate in these two samples was due to the stacking of the small crystallites with the same orientation. In fact, electron diffraction patterns obtained from a single sphere consisted of well-defined spots, like a single-crystal pattern, with a definite zone axis. By tilting 
the sample in a large angular range $\left(+-60^{\circ}\right)$, different zone axis could be selected, demonstrating the ordered rigorous stacking up of the crystallites, which was not of spherical symmetry. Crystallites are stacked parallel to the $\{111\},\{110\}$ and $\{100\}$ planes with the lower surface energy [51-52]. In the $\mathrm{CM}_{0.5} \mathrm{P}_{3}$ sample, crystallites started to lose their preferential orientation, as shown by the presence of bows and the formation of rings in the electron diffraction pattern, although obtained from a single sphere (Fig. 6a).

\subsection{EPR characterization}

EPR spectra, with a signal at $\mathrm{g}=2$ and a hyperfine structure were characteristic of $\mathrm{Mn}$ II [53] (Fig. 7a). Both the absence of any change with temperature (blue curve at $15 \mathrm{~K}$ and green curve at 25 $\mathrm{K}$ ) and the presence of the hyperfine structure indicated that $\mathrm{Mn} \mathrm{II} \mathrm{species} \mathrm{were} \mathrm{isolated} \mathrm{and} \mathrm{without}$ any strong interaction with the other $\mathrm{Mn}$ II species. Moreover, at least two types of $\mathrm{Mn}$ II were detected, revealing two different distances between two Mn II centers. The coordination environment of $\mathrm{Mn}$ II is a distorted octahedral. The presence of Mn II species was explained by the substitution of cerium with manganese in ceria. The $\mathrm{Mn}$ II species were found to be more present in the $\mathrm{CM}_{0.5} \mathrm{P}_{3}$ sample (blue line) than in the $\mathrm{CM}_{0.5} \mathrm{P}_{0}$ sample (red line). The EPR analysis confirmed the XRD observations relative to the easier formation of the solid solution in the presence of the polymer. Further EPR experiments realized in perpendicular mode (Fig. 7b) confirmed the presence of at least two types of isolated Mn II species located inside ceria, with low interaction with other Mn II in the ceria framework. A signal characteristic of Mn IV at $\mathrm{g}=4$, with a lower resolution, was also observed [54]. Moreover, additional information was obtained from the simulation of an experimental spectrum obtained in parallel mode (Fig. 7c). Simulations of the spectrum were done with the following

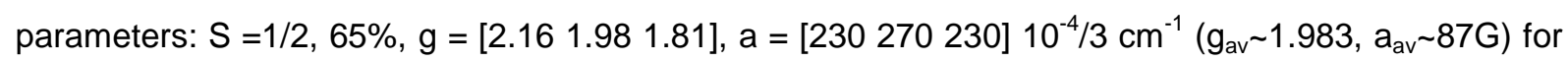
Mn II species; $S=3 / 2,35 \%, g=\left[\begin{array}{ll}2 & 1.991 .985\end{array}\right], D=0.036710^{-4} \mathrm{~cm}^{-1}, E / D=0.05$ for Mn IV species, where a corresponds to the hyperfine interaction tensor (electron- nucleus) and $D$ and $E$ are the zero field interaction tensors (high spin, $\mathrm{E}=0$, axial, $\mathrm{E} \# 0$, rhombic asymmetry). The presence of $\mathrm{Mn}$ III species could not be excluded. Indeed, $\mathrm{Mn}$ III is difficult to observe by EPR in oxides. So, $\mathrm{Mn}_{3} \mathrm{O}_{4}$, as attested by the XRD data could not be observed by EPR as shown by Lopez-Ortega \& al. [55]. In addition, no trace of superoxide radicals, which are usually characterized by a sharp signal at $g=2$, was evidenced. Finally, these simulations allowed to estimate the ratio of the Mn II to Mn IV signals to 
1.85 in the $\mathrm{CM}_{0.5} \mathrm{P}_{3}$ sample. Mn IV represents $35 \%$ of the EPR signal, while Mn II represents $65 \%$ of the EPR signal. A broad signal at $\mathrm{g}=2.6$ was also observed in the blue spectrum acquired at $25 \mathrm{~K}$ (blue line, Fig. 7c). The simulation performed with only one undistorted $M n$ II species ( $D=0)$ could not reproduce this broad signal. Two Mn II species had to be considered: one undistorted Mn II $(D=0)$ and another type of $\mathrm{Mn}$ II with some distortion (D\#0).

\subsection{Raman analysis}

Raman spectra are presented in Figure 8. Only one peak was noticed at $463 \mathrm{~cm}^{-1}$ in the pure ceria samples $\left(\mathrm{CM}_{0} \mathrm{P}_{0}\right.$ and $\mathrm{CM}_{0} \mathrm{P}_{3}$ samples Fig.8a \& $\left.8 \mathrm{~b}\right)$. This peak was attributed to the symmetric breathing mode of oxygen atoms around the cerium ions in the cerium oxide cubic-phase [45]. The presence of the polymer resulted in an increase of the FWHM of the Raman bands, associated to a decrease of the crystallite size. Without PVP and upon manganese addition, for a $\mathrm{Mn}: \mathrm{Ce}$ ratio of 0.5 (Fig. 8c), a broad vibration was noted at $463 \mathrm{~cm}^{-1}$ with a second one at $620 \mathrm{~cm}^{-1}$. This second one vibration is related to the stretching mode of manganese-oxygen bound. For a $\mathrm{Mn}$ :Ce ratio of 1 (Fig. 8e), two vibrations were seen at $463 \mathrm{~cm}^{-1}$ and $650 \mathrm{~cm}^{-1}$. In the case of PVP addition and upon manganese addition, for a Mn:Ce ratio of 0.5 (Fig. 8d), a broader vibration band was observed at 450 $\mathrm{cm}^{-1}$ with a second one at $630 \mathrm{~cm}^{-1}$. While for a Mn:Ce ratio of 1 (Fig. 8f), two vibrations are noted at $450 \mathrm{~cm}^{-1}$ and $645 \mathrm{~cm}^{-1}$. Then, in the case of PVP addition, the shift towards lower wavenumbers of the ceria vibration from 463 to $450 \mathrm{~cm}^{-1}$ might be related to the formation of a solid solution [47]. As it has been already noted from XRD analysis, PVP plays a decisive role in the formation of the solid solution between manganese and cerium. Upon adding manganese, for a Mn:Ce ratio of 0.5 , an increase of the full width at half maximum (FWHM) of the ceria vibration band (at $450 \mathrm{~cm}^{-1}$ or $463 \mathrm{~cm}^{-1}$ ) was also observed. Similar observations have been made in the case of $\mathrm{Cu}-\mathrm{Ce}-\mathrm{O}$ materials: an increase of the FWHM of the Raman bands was observed when the copper content increased. Such increase has been related to an increase in the concentration of the oxygen vacancies and to a decrease of the crystallite size [56]. The second vibration at $640 \mathrm{~cm}^{-1}$ was due to the $\mathrm{Mn}-\mathrm{O}$ stretching mode in manganese oxides, revealing that part of the manganese species was not inserted inside ceria [47]. However, it was difficult to distinguish between $\mathrm{MnO}_{2}$ and $\mathrm{Mn}_{3} \mathrm{O}_{4}$. In fact, vibration bands characteristic of $\mathrm{MnO}_{2}$ would appear at 602 and $648 \mathrm{~cm}^{-1}$ while the one related to the $\mathrm{Mn}_{3} \mathrm{O}_{4}$ is expected at $654 \mathrm{~cm}^{-1}$ [47]. We can also observe that the intensity of the Mn-O stretching mode is higher when no PVP has 
been added which may also been explained by the fact that the polymer has prevented the manganese oxide crystallization and has favored the solid solution formation.

\subsection{Thermal analyses}

TGA/SDTA experiments were realized under air (Fig.9) The TGA curve for $\mathrm{MnO}_{2}$ revealed (i) a dehydration step characterized by a first weight loss related to the physically adsorbed water; (ii) a second weight loss, attributed to the reduction of $\mathrm{MnO}_{2}$ to $\mathrm{Mn}_{5} \mathrm{O}_{8}$ (Fig. 9a); (iii) a third weight loss, starting at around $400^{\circ} \mathrm{C}$, associated to an endothermic peak on SDTA curve, and corresponding to the formation of $\mathrm{Mn}_{2} \mathrm{O}_{3}$; (iv) a fourth weight loss, at around $900^{\circ} \mathrm{C}$, related to the subsequent endothermic reduction of $\mathrm{Mn}_{2} \mathrm{O}_{3}$ to $\alpha-\mathrm{Mn}_{3} \mathrm{O}_{4}$ and $(\mathrm{v})$ on the SDTA curve, a last endothermic transition at about $1140^{\circ} \mathrm{C}$ due to the transformation of $\alpha-\mathrm{Mn}_{3} \mathrm{O}_{4}$ into $\beta-\mathrm{Mn}_{3} \mathrm{O}_{4}$. TGA of $\mathrm{CM}_{0} \mathrm{P}_{3}$ (Fig. 9b) showed a first weight loss below $200^{\circ} \mathrm{C}$ attributed to the loss of water and a second continuous weight loss from $200^{\circ} \mathrm{C}$ till $1200^{\circ} \mathrm{C}$, similar to the TGA profile obtained in the case of pure ceria [57]. TGA/SDTA of $\mathrm{CM}_{0.25} \mathrm{P}_{3}$ showed the same progressive weight loss (Fig. 9c) as well as very small losses around 500 and $900^{\circ} \mathrm{C}$. One possible interpretation is that most of the manganese was present as $\mathrm{Mn} \mathrm{II}$, probably because manganese was essentially inside the ceria lattice, but some Mn IV was also present in the sample as attested by the EPR analysis. TGA/SDTA of $\mathrm{CM}_{0.5} \mathrm{P}_{3}$ showed a first loss below $200^{\circ} \mathrm{C}$ due to the loss of water, a second marked weight loss at $450^{\circ} \mathrm{C}$, and a third marked weight loss at $900^{\circ} \mathrm{C}$ (Fig. 9c). By analogy with the behaviour of the $\mathrm{MnO}_{2}$ sample (fig. 9a), the second loss was attributed to the reduction of $\mathrm{Mn} \mathrm{IV}$ into $\mathrm{Mn} \mathrm{III}$, and to the formation of $\mathrm{Mn}_{2} \mathrm{O}_{3}$. Moreover, the third weight loss at $900^{\circ} \mathrm{C}$ was associated to the reduction of $\mathrm{Mn}$ III species into $\mathrm{Mn} \mathrm{II}$ and the formation of $\mathrm{Mn}_{3} \mathrm{O}_{4}$. This analysis seems to indicate that, part of the manganese was involved in a solid solution with ceria while another part was located outside of the ceria particles, since two distinct reduction steps of the Mn IV species into $\mathrm{Mn}$ III and $\mathrm{Mn}$ II have been observed, associated to two endothermic signals. This analysis also suggested the presence of Mn IV species in the $\mathrm{CM}_{0.5} \mathrm{P}_{3}$, as attested already by the EPR analysis. These Mn IV species might be inserted inside ceria or located at the ceria surface since no $\mathrm{MnO}_{2}$ phase could be detected by XRD or TEM analyses. The $0.4 \%$ weight loss at $900^{\circ} \mathrm{C}$, measured in the case of the $\mathrm{CM}_{0.5} \mathrm{P}_{3}$ sample, attributed to the reduction of $\mathrm{Mn}_{2} \mathrm{O}_{3}$ into $\mathrm{Mn}_{3} \mathrm{O}_{4}$, was used to estimate the fraction of Mn IV in the sample, which might be considered as "free" (not inserted inside the ceria lattice). The following composition could be estimated for the fresh sample: Ce 
$\mathrm{Mn}(\text { reduced })_{0.2} \mathrm{O}_{2.2}+0.15 \mathrm{Mn}_{2} \mathrm{O}_{3}$. After treatment at $900^{\circ} \mathrm{C}$, the composition would be Ce$\mathrm{Mn}(\text { reduced })_{0.2}-\mathrm{O}_{2.2}+0.10 \mathrm{Mn}_{3} \mathrm{O}_{4}$. It is suggested that the initial composition is not far from $\mathrm{Ce}$ $\mathrm{Mn}(\text { reduced })_{0.2} \mathrm{Mn}$ (oxidized) $)_{0.3} \mathrm{O}_{2.8}$, in which the reduced of $\mathrm{Mn}$ can be either inside ceria or as free $\mathrm{Mn}$ as $\mathrm{Mn}_{3} \mathrm{O}_{4}$. The TGA analysis of the $\mathrm{CM}_{1} \mathrm{P}_{3}$ sample (Fig. 9c) was found to be somehow an intermediate between the $\mathrm{CM}_{0.5} \mathrm{P}_{3}$ and the $\mathrm{CM}_{0.25} \mathrm{P}_{3}$ samples. This result can be understood considering that fraction of manganese entered inside ceria and that the manganese in excess is mostly present as the hausmannite $\mathrm{Mn}_{3} \mathrm{O}_{4}$ phase, indicating that the overall manganese oxidation state was lower. The $0.3 \%$ weight loss at $900^{\circ} \mathrm{C}$ was coherent with a higher proportion of $\mathrm{Mn}$ in a reduced state, compared to the $\mathrm{CM}_{0.5} \mathrm{P}_{3}$ sample. This results showed that the Mn:Ce ratio had a strong influence on the overall manganese oxidation state. The presence of cerium IV certainly contributed to the stabilization of manganese IV. At low Mn:Ce ratio, Mn was found either as $\mathrm{Mn} \mathrm{II} \mathrm{in}$ ceria or as Mn IV. At intermediate Mn:Ce ratio, manganese was still stabilized as Mn IV, but Mn IV could be reduced at high temperature. However, when the Mn:Ce ratio further increased, manganese was mostly stabilized in a reduced state (hausmannite $\mathrm{Mn}_{3} \mathrm{O}_{4}$ ).

\subsection{Textural analyses}

Textural characterizations were carried out using nitrogen adsorption/desorption isotherms. The results are summarized in Table 1 and Figure 10. Specific surface areas were usually around 60 $\mathrm{m}^{2} . \mathrm{g}^{-1}$ except for the $\mathrm{CM}_{0.5} \mathrm{P}_{3}$ and $\mathrm{CM}_{0.5} \mathrm{P}_{1}$ samples where higher specific surface area around 100 $\mathrm{m}^{2}$. $\mathrm{g}^{-1}$ was obtained (Fig. 10a \& 10d). The hysteresis loop indicated the presence of mesopores. Using the Barret-Joyner-Halenda (BJH) model, the pore size distribution could be derived from the desorption branch. The maximum pore radius was around $11 \mathrm{~nm}$ and the mesoporous volume was equal to $0.21 \mathrm{~cm}^{3} \cdot \mathrm{g}^{-1}$. The higher porosity observed for the $\mathrm{CM}_{0.5} \mathrm{P}_{3}$ and $\mathrm{CM}_{0.5} \mathrm{P}_{1}$ samples was in agreement with the snowflake morphology observed by TEM (Fig. 5c \& 5f).

\subsection{Hydrothermal treatment}

Such manganese-cerium mixed oxides could potentially be used as catalyst for the treatment of aqueous effluents in a process which is called catalytic wet air oxidation (CWAO) [28]. In such process, pollutants in water are eliminated using oxygen at high pressure and temperature. Before to study such catalytic process, we need to know if these compounds are stable under hydrothermal 
conditions. The hydrothermal stability of the $\mathrm{CM}_{0.5} \mathrm{P}_{3}$ compound treated at $400^{\circ} \mathrm{C}$ was evaluated upon heating the sample at $200^{\circ} \mathrm{C}$ in water for $24 \mathrm{~h}$. The sample changed from brown to black. X-ray diffraction pattern (Fig. 11a) revealed the formation of a crystallized bixbyite phase $\left(\mathrm{Mn}_{2} \mathrm{O}_{3}\right)$ characterized by the apparition of the (222) reflection at $32.9^{\circ}$ (ICDD $n^{\circ}$ 01-089-4836). After hydrothermal treatment, the solid solution $\mathrm{MnCeO}$ crystallinity is improved since XRD intensity is higher. The influence of this hydrothermal treatment on the crystallite size (peak width) and on the textural properties is slight. Indeed the textural properties are preserved (Fig. 10b and Table 1) even if the mesoporous volume and the pore size have been a little increased. The micron-sized spherical morphology with a hole is conserved but whiskers of $\mathrm{Mn}_{2} \mathrm{O}_{3}$ were observed by SEM on the surface of the $\mathrm{CM}_{0.5} \mathrm{P}_{3}$-h sample (Fig. 11b). The crystallite assembly always lead to snowflakes of 100 to $200 \mathrm{~nm}$ diameter (Fig. 11c \& 11d), which aggregate in spheres with a hole (Fig. 11b), as they were before the thermal treatment.

\section{Discussion}

Upon solvothermal treatment of a mixture of cerium and manganese nitrates, in the presence of polyvinylpyrrolidone (PVP), different solids with different morphologies could be prepared. The final product characteristics were shown to be highly dependent on the reaction conditions (Mn:Ce ratio and PVP concentration). Adding the PVP polymer which is a well-known capping agent for ceria seeds has a decisive influence on the morphology and structure of the compounds obtained. XRD and Raman analysis have shown that it has favoured the formation of a solid solution of manganese and cerium, probably by promoting the diffusion of manganese around the ceria seeds. In the absence of manganese, i.e. in the case of pure ceria, "spherical-type" objects (300 nm in diameter) were formed, with a very high textural organization. The organization of the crystallites induced by the presence of PVP has already been noticed as well as the formation of "spherical-type" objects [58]. A remarkable orientation of the crystallites occurs, leading to the construction of larger size (300 nm) spherical edifices. At first, the Oswald ripening mechanism, dissolution of the smaller particles and the recrystallization of larger particles, has been proposed to explain the formation of such morphologies [14]. However, a spontaneous self-organization of adjacent particles, inducing the sharing a common crystallographic orientation, might also be involved [10]. This mechanism called the "oriented attachment" has recently been shown to be predominant $[9,10,18,19]$. The morphology observed in 
our study looks very similar to what has been obtained by Zhou et al., upon synthesis in water at $140^{\circ} \mathrm{C}$ [18]. These authors obtained submicronic spheres formed by the aggregation of $5 \mathrm{~nm}$ crystallites. They have also reported a correlation between the sphere's size and the PVP/Ce ratio or the cerium concentration. On the opposite, our result differed from what was obtained by Chen et al., whom noticed the formation of $100 \mathrm{~nm}$ octahedral nanocrystals, upon synthesis in a mixture of water and ethanol at $160^{\circ} \mathrm{C}$ [14]. Such difference might be explained by the higher cerium and PVP concentrations involved in our study.

At low manganese concentration, $\mathrm{Mn}: \mathrm{Ce}=0.25$, a solid solution $\mathrm{Mn}-\mathrm{Ce}$ oxide was obtained with "spherical-type" objects of $100 \mathrm{~nm}$ in diameter. These spheres consisted of smaller ceria crystallites, still remarkably ordered. EPR characterizations showed that (i) isolated Mn II was found inside the ceria lattice and that (ii) Mn IV was also present, localized either inside or near the ceria surface. TGA analysis revealed that such Mn IV species were not easily reducible. For a Mn:Ce ratio equal to 0.5 , a $\mathrm{MnCeO}$ solid solution was mixed with a reducible Mn IV containing phase, resulting either from the Mn IV insertion inside ceria or from the "adsorption" of Mn IV species at the ceria surface. This later suggestion derives from the EPR analysis indicating the presence of Mn IV and the TGA analysis demonstrating that these $\mathrm{Mn}$ IV species were as reducible as in "free" $\mathrm{MnO}_{2}$. At such high manganese ratio, the ceria crystallite size decreased $(3 \mathrm{~nm})$ and the ordering of the crystallites also decreased. Smaller spheres with a snowflake-like shape were formed. Finally, large micrometric "spherical-type objects" with a hole were obtained by aggregation of these small snowflakes. In fact, micrometric spheres of $\mathrm{MnO}_{2}$ have been frequently reported to form upon solvothermal synthesis [59]. For the highest $\mathrm{Mn}: \mathrm{Ce}$ ratio of 1 , the $\mathrm{Mn}-\mathrm{Ce}$ solid solution existed together with the hausmannite phase $\left(\mathrm{Mn}_{3} \mathrm{O}_{4}\right)$. The snowflake like morphology was maintained but the specific micrometric sphere morphology was lost. In the case of a pure manganese sample, flower-like micrometric $\mathrm{Mn}_{3} \mathrm{O}_{4}$ objects were obtained.

The evolution of textural properties summarized in the Table 1 might be better understood in the light of the TEM observations. In the case of pure ceria, the aggregation of large rectangular crystallites induced the formation of large pores. Indeed, the "orientated aggregation" of small ceria crystallites into larger irregular truncated octahedral crystals was shown to induce the formation of pores [9]. Moreover, in the $\mathrm{CM}_{0.25} \mathrm{P}_{3}$ sample, smaller and more isotropic crystallites were aggregated, in a more compact stacking, leading to the absence of any porosity. Finally, in the case of the $\mathrm{CM}_{0.5} \mathrm{P}_{3}$ 
sample, the snowflake-like porous structure was obtained by the aggregation of very small crystallites, which explained the higher specific surface area and the higher porous volume.

EPR results showed that there was some Mn II inside the ceria lattice in substitution position. The $\mathrm{Mn}_{3} \mathrm{O}_{4}$ phase was detected by XRD but it could not be evidenced by EPR. Indeed, strongly interacting $\mathrm{Mn}$ III species are difficult to observe and strongly interacting $\mathrm{Mn}$ II might not be distinguished from the isolated Mn II species [55]. Manganese IV was also evidenced, either as Mn IV inserted in the ceria lattice or as Mn IV as the outer ceria surface. These data should be compared with the literature. At least two types of Mn II species have already been observed in some $\mathrm{Mn}-\mathrm{Ce}$ oxide samples. The absence of Mn IV species was reported. The presence of Mn III species, difficult to prove by EPR analysis, was deduced from other experiments [37]. In other studies, it has been clearly observed that Mn II replaced Ce IV in ceria, as evidenced by XPS [60] or Rietveld analysis [61]. Two recent studies have shown that a limited fraction of manganese was present in a solid solution with ceria, while the other part of manganese was segregated around the ceria crystallites in the grain boundary. It was manifested by a crystallite size decrease and a specific surface area increase [43,62]. Our EPR results were also consistent with such hypothesis since the Mn IV signal could be explained by the segregation of manganese at the outer ceria surface. In fact, such kind of segregation at the grain boundary is frequently observed when ceria is doped with rare-earths $[63,64]$ and the accumulation of cation at the grain boundaries is found to coincide with the oxygen vacancy accumulation. The micron-sized spherical morphology obtained in this work for the $\mathrm{Mn}$ :Ce ratio of 0.5 , may result from this manganese segregation, inducing a cohesion between the $\mathrm{Mn}$-Ce oxide crystallites. Our work could be compared with previous studies on mixed manganese cerium oxide via solvothermal synthesis. A new snowflake-like porous morphology in the CeMn oxide system, formed by the oriented attachment of small crystallites, has been obtained by the proposed method, which differs from the rods and cubes or flowers previously synthesized [24,25]. The particular snow-flake porous morphology of the cerium-manganese mixed oxide which has been obtained in this work results from the polyvinylpyrrolidone addition. Indeed, the PVP polymer behaves as a capping agent around the ceria seeds and promotes the manganese ions dispersion on the ceria seeds.

\section{Conclusions}


Reactions involving manganese and cerium salts in the presence of PVP as a capping ligand and structuring agent in a solvothermal process led to $\mathrm{Mn}$-Ce oxides with snowflake-like morphology. Manganese was partly introduced as $\mathrm{Mn}$ II inside the ceria lattice. For a Mn:Ce ratio of 0.25 , small spheres of $100 \mathrm{~nm}$ in diameter were formed, consisting of a Mn-Ce oxide solid solution. The other fraction of the manganese was present as Mn IV, near the ceria surface. Furthermore, these later crystallites were found to be highly oriented. For a Mn:Ce ratio of 0.5 , smaller snowflake-like spheres of a MnCe oxide were successfully synthesized. These snowflakes were aggregated into large porous micrometric spheres. At higher Mn:Ce ratio, snowflake-like spheres of Mn-Ce oxide were mixed with $\mathrm{Mn}_{3} \mathrm{O}_{4}$. The hydrothermal stability of such compound was also studied and the crystallization of a bixbyite phase $\left(\mathrm{Mn}_{2} \mathrm{O}_{3}\right)$, out of the ceria was observed. However, the texture of the solid was preserved.

\section{Acknowlegments}

This work was financially supported by the Région Rhône-Alpes. The authors gratefully acknowledge the Region Rhône-Alpes for the Ph. D. grant awarded to France Schmit for the period 2011-2014. The authors gratefully acknowledge the national EPR network TGE RENARD, FR 3443-CNRS and the CT $\mu$ platform of electronic microscopy (University Lyon 1). Nicolas Blanchard, Institut Lumière Matière, Université Lyon 1, is acknowledged for his help during the TEM observations. 


\section{References}

[1] G. Chen, F. Rosei, D. Ma, Adv. Funct. Mater. 22 (2012) 3914-3920.

[2] D. Zhang, X. Du, L. Shi, R. Gao, Dalton Trans. 41 (2012) 14455-14475

[3] C. Sun, H. Li, L. Chen, Energy Environ. Sci. 5, (2012) 8475-8505.

[4] Q. Yuan, H-H. Duan, L-L. Li, L-D. Sun, Y-W. Zhang, C-H. Yan, J. Colloid. Interf. Sci. 335 (2009) 151-167.

[5] C. Sun, H. Li, H. Zhang Z. Wang, L. Chen, Nanotechnology, 16 (2005) 1454-1463.

[6] C. Sun, J. Sun, G. Xiao, H. Zhang, X. Qiu, H. Li, L. Chen, J. Phys. Chem. B, 110, 27 (2006) 13445-13452.

[7] C. Sun, H. Li, L. Chen, J. Phys. \& Chem. Sol. 68, 9 (2007) 1785-1790.

[8] C. Sun, L. Chen, Eur. J. Inorg. Chem. 26 (2009) 3883-3887.

[9] H.R. Tan, J.P.Y. Tan, C. Boothroyd, T.W. Hansen, Y.L. Foo, M. Lin, J. Phys. Chem. C. 116, 1 (2012) 242-247.

[10] J.P.Y. Tan, H.R. Tan, C. Boothroyd, Y.L. Foo, C.B. He, M. Lin, J. Phys. Chem. C. 115, 9 (2011) 3544-3551.

J. Wei, Z. Yang, Y. Yang, Cryst. Eng. Comm. 13 (2011) 2418-2424.

[12]

[13]

S. Phokha, S. Pinitsoontorn, P. Chirawatkul, Y. Poo-Arporn, S. Maensiri, Nanoscale Res. Lett. 7, (2012) 425-437.

T. Itoh, T. Uchida, N. Izu, I. Matsubara, W. Shin, Materials, 6, 6 (2013) 2119-2129.

G. Chen, F. Zhu, X. Sun, S. Sun, R. Chen, Cryst. Eng. Comm,13 (2011) 2904-2908.

Z. Yang, D. Han, D. Ma, H. Liang, L. Liu, Y. Yang, Cryst. Growth. Design. 10 (2010) 291-295

[16] Z. Yang, J. Wei, H. Yang, L. Liu, H. Liang, Y. Yang, Eur. J. Inorg. Chem. 21 (2010) 3354-3359.

[17] X. Han, L. Li, C. Wang, Cryst.Eng.Comm. 14 (2012) 1939-1941.

[18] F. Zhou, X. Zhao, H. Xu, C. Yuan, J. Phys. Chem. C, 111, 4 (2007) 1651-1657.

[19] M. Lin, Z.Y. Fu, H.R. Tan, J.P.Y. Tan, S. C. Ng, E. Teo, Cryst. Growth Des. 12, 6 (2012) 3296-3303. 

1266.

H.C. Genuino, S. Dharmarathna, E.C. Njagi, M.C. Mei, S.L. Suib, J. Phys. Chem. C. 116, 22 (2012) 12066-12078. 25551.

M. Wiechen, M.M. Najafpour, S.I. Allakhverdiev, L. Spiccia, Energy Environ. Sci. 7 (2014) 2203-2212.

H. Li, G. Lu, Q. Dai, Y. Wang, Y. Guo, Y. Guo, Appl. Cat. B: Env. 102, 3-4 (2011) 475483.

H. Li, G. Qi, Tana, X. Zhang, W. Li, W. Shen, Catal. Sci. Technol. 1 (2011) 1677-1682.

F. Arena, Catal. Sci. Technol. 4 (2014) 1890-1898.

X. Tang, J. Chen, X. Huang, Y. Xu, W. Shen, Appl. Catal. B: Env. 81, 1-2 (2008) 115121.

J.A. Perez-Omil, J.J. Delgado, W. Ouahbi, A.B. Hungrıa, N. Browning, M.A. Cauqui, J.M. Rodrıguez-Izquierdo, J.J. Calvino, J. Phys. Chem. C. 114, 19 (2010) 8981-8991.

D. Delimaris, T. loannides, Appl. Catal. B: Env. 84, 1 (2008) 303-312.

D. Jampaiah, K.M. Tur, S.J. Ippolito, Y.M. Sabri, J. Tardio, S.K. Bhargava, B.M. Reddy, RSC Advances, 3 (2013) 12963-12974.

Y. Liao, M. Fu, L. Chen, J. Wu, B. Huang, D. Ye, Catalysis Today, 216 (2013) 220228.

X. Tang, Y. Li, X. Huang, Y. Xu , H. Zhu, J. Wang, W. Shen, Appl. Catal. B: Env. 62 (2006) 265-273. J. Phys. Chem. C, 117, 19 (2013) 9999-10006.

A. Gupta, U.V. Waghmare, M.S. Hegde, Chem. Mater. 22, 18 (2010) 5184-5198.

B. Murugan, A. V. Ramaswamy, D. Srinivas, C. S. Gopinath, V. Ramaswamy, Chem. Mater. 17, 15 (2005) 3983-3993. 
B. Murugan A.V. Ramaswamy, D. Srinivas, C.S. Gopinath, V. Ramaswamy, Acta. Mater. 56, 7 (2008) 1461-1472.

W. Cen, Y. Liu, Z. Wu, H. Wang, X. Weng, Phys. Chem. Chem. Phys. 14 (2012) 57695777.

M.D. Krcha, M.J. Janik, Langmuir, 29, 32 (2013) 10120-10131.

D. García Pintos, A. Juan, B. Irigoyen, J. Phys. Chem. C. 117, 35 (2013) 18063-18073. 777-779.

H. T. Handal, V. Thangadurai, J. Power Sources, 243 (2013) 458-471.

C.H.Y. Kang, H. Kusaba, H. Yahiro, K. Sasaki, Y.Teraoka, Solid State Ionics, 177, 19 (2006) 1799-1802.

R. Li, M.D. Krcha, M.J. Janik, A.D. Roy, K.M. Dooley, Energy Fuels, 26, 11 (2012) 6765-6776.

S. Imamura, A. Dol, S. Ishida, Ind. Eng. Chem. Prod. Res. Dev. 24, 1 (1985) 75-80.

W.J. Hong, S. Iwamoto, S. Hosokawa, K. Wada, H. Kanai, M. Inoue, J. Catalysis. 277 (2011) 208-216.

Y. Tang, H. Qiao, H. Wang, P. Tao, J. Mater. Chem. A, 1 (2013) 12512-12518.

9] X. Liu, H. Yang, L. Han, W. Liu, C. Zhang, X. Zhang, S. Wang, Y. Yang, Cryst. Eng. Comm. 15 (2013) 7769-7775.

[54] K. A. Campbell, M. R. Lashley, J. K. Wyatt, M. H. Nantz, R. David Britt, J. Am. Chem. Soc. $2001,123,5710-5719$. 
A. Lopez-Ortega, D. Tobia, E. Winkler, I.V. Golosovsky, G. Salazar-Alvarez, S. Estrade, M. Estrader, J. Sort, M. A. Gonzalez, S. Surinach, J. Arbiol, F. Peiro, R.D. Zysler, M. D. Baro, J. Nogues, J. Am. Chem. Soc. 132, 27 (2010) 9398-9407.

[56] A. Aranda, E. Aylon, B. Solsona, R. Murillo, A.M. Mastral, D.R. Sellick, S. Agouram, T. Garcıa, S.H. Taylor, Chem. Commun. 48 (2012) 4704-4706.

[57] E. Aneggi, D. Wiater, C. de Leitenburg, J. Llorca, A. Trovarelli, ACS Catal. 4,1 (2014) $172-181$.

[58] S. Horiuchi, T. Hanada, N. Izu, I. Matsubara, J. Nanopart. Res. 14 (2012) 734-743.

[59] D. Li, X. Wu, Y. Chen, J. Phys. Chem. C. 117, 21 (2013) 11040-11046.

[60] S. Saravanakumar, S. Sasikumar, S. Israel G.R. Pradhiba, R. Saravanan, Materials Science in Semiconductor Processing, 17 (2014) 186-193.

[61] C. Xia, C. Hu, P. Chen, B. Wan, X. He, Y. Tian, Mat. Research Bull. 45, 7 (2010) 794798.

[62] L. Wu, S. Dey, M. Gong, F. Liu, R.H.R. Castro, J. Phys. Chem. C. 118, 51 (2014) 30187-30196.

[63] H.B. Lee, F.B. Prinz, W. Cai, Acta Materialia, 61 (2013) 3872-3887.

[64] Y. Lei, Y. Ito, N.D. Browning, T.J. Mazanec, J. Am. Ceram. Soc. 85 (2002) 2359-2363. 
Table:

\begin{tabular}{|c|c|c|c|c|c|c|c|}
\hline & $\begin{array}{c}\text { Mn/Ce } \\
\text { ratio }\end{array}$ & $\begin{array}{c}\text { Specific } \\
\text { Surface } \\
\text { area }\left(\mathbf{m}^{2} / \mathbf{g}\right)\end{array}$ & $\begin{array}{c}\text { Mesoporous } \\
\text { volume } \\
\left(\mathbf{c m}^{3} / \mathbf{g}\right)\end{array}$ & $\begin{array}{c}\text { Porous } \\
\text { volume } \\
\left(\mathbf{c m}^{3} / \mathbf{g}\right)\end{array}$ & $\begin{array}{c}\text { Max pore } \\
\text { radius } \\
(\mathbf{n m})\end{array}$ & $\begin{array}{c}(\mathbf{2 2 0}) \\
\text { width }\left(^{\circ}\right)\end{array}$ & $\begin{array}{c}\text { Crystallite } \\
\text { size (nm) }\end{array}$ \\
\hline $\mathbf{C M}_{\mathbf{0}} \mathbf{P}_{\mathbf{3}}$ & $0 / 1$ & 59 & 0.10 & 0.22 & 7 & 0.55 & 16 \\
\hline $\mathbf{C M}_{0.25} \mathbf{P}_{\mathbf{3}}$ & $0.25 / 1$ & 58 & 0.03 & 0.06 & 1.7 & 1.60 & 5.8 \\
\hline $\mathbf{C M}_{0.5} \mathbf{P}_{\mathbf{3}}$ & $0.5 / 1$ & 108 & 0.16 & 0.21 & 11 & 2.33 & 3.9 \\
\hline $\mathbf{C M}_{\mathbf{1}} \mathbf{P}_{\mathbf{3}}$ & $1 / 1$ & 70 & 0.05 & 0.06 & 2.0 & 2.08 & 4.0 \\
\hline $\mathbf{C M}_{\mathbf{0 . 5}} \mathbf{P}_{\mathbf{0}}$ & $0.5 / 1$ & 30 & 0.03 & 0.05 & 1.7 & 1.36 & 6.8 \\
\hline $\mathbf{C M}_{\mathbf{0 . 5}} \mathbf{P}_{\mathbf{1}}$ & $0.5 / 1$ & 97 & 0.16 & 0.19 & 1.9 & 1.68 & 5.5 \\
\hline $\mathbf{C M}_{\mathbf{0 . 5}} \mathbf{P}_{\mathbf{3}} \mathbf{- h}$ & $0.5 / 1$ & 92 & 0.21 & 0.25 & 14 & 2.17 & 4.2 \\
\hline
\end{tabular}

Table 1 : Textural properties of $\mathrm{CM}_{\mathrm{x}} \mathrm{P}_{\mathrm{y}}$ samples. 


\section{Figures caption.}

Figure 1: $a, b$ : TEM pictures of the $\mathrm{CM}_{0.5} \mathrm{P}_{3}$ sample as obtained after the solvothermal treatment at $200^{\circ} \mathrm{C}$.

Figure 2: $a$ : TGA and b: SDTA curves of the $\mathrm{CM}_{0.5} \mathrm{P}_{3}$ sample after the solvothermal treatment at $200^{\circ} \mathrm{C}$.

Figure 3: X-ray diffraction patterns of the $\mathrm{CM}_{\mathrm{x}} \mathrm{P}_{\mathrm{y}}$ samples. a: $\mathrm{CM}_{0} \mathrm{P}_{3}, \mathrm{CM}_{0.25} \mathrm{P}_{3}, \mathrm{CM}_{0.5} \mathrm{P}_{3}, \mathrm{CM}_{1} \mathrm{P}_{3}, \mathrm{MP}_{3}$ samples, Inset: zoom on the (111) reflection; b: $\mathrm{CM}_{0.5} \mathrm{P}_{0}, \mathrm{CM}_{0.5} \mathrm{P}_{1}, \mathrm{CM}_{0.5} \mathrm{P}_{3}$ samples, Inset: zoom on the (111) reflection.

Figure 4: SEM pictures of the $\mathrm{CM}_{x} \mathrm{P}_{\mathrm{y}}$ samples. a: $\mathrm{CM}_{0.5} \mathrm{P}_{0}$; b: $\mathrm{CM}_{0.5} \mathrm{P}_{1} ; \mathrm{c}$ : $\mathrm{CM}_{0.5} \mathrm{P}_{3} ; \mathrm{d}: \mathrm{CM}_{0} \mathrm{P}_{3}$; e: $\mathrm{CM}_{0.25} \mathrm{P}_{3} ; \mathrm{f:} \mathrm{MP}_{3}$.

Figure 5: TEM pictures of the $\mathrm{CM}_{x} \mathrm{P}_{\mathrm{y}}$ samples. a: $\mathrm{CM}_{0.5} \mathrm{P}_{3} ;$ b: $\mathrm{CM}_{0.25} \mathrm{P}_{3} ; \mathrm{c}: \mathrm{CM}_{0.5} \mathrm{P}_{3} ; \mathrm{d}: \mathrm{CM}_{1} \mathrm{P}_{3}$; e: $\mathrm{CM}_{0.5} \mathrm{P}_{0} ; \mathrm{f}: \mathrm{CM}_{0.5} \mathrm{P}_{1}$.

Figure 6: TEM, HRTEM pictures and electron diffraction patterns on a single sphere. a, b c: $\mathrm{CM}_{0} \mathrm{P}_{3} ; \mathrm{d}$, e, f: $\mathrm{CM}_{0.25} \mathrm{P}_{3} ; \mathrm{g}, \mathrm{h}, \mathrm{i}: \mathrm{CM}_{0.5} \mathrm{P}_{3}$ samples.

Figure 7 a : EPR spectra, parallel mode, $\mathrm{CM}_{0.5} \mathrm{P}_{3}(15 \mathrm{~K}), \mathrm{CM}_{0.5} \mathrm{P}_{0}(15 \mathrm{~K}), \mathrm{CM}_{0.25} \mathrm{P}_{3}(15 \mathrm{~K}), \mathrm{CM}_{0.5} \mathrm{P}_{3}(25 \mathrm{~K})$;

b : EPR spectra, perpendicular mode, $\mathrm{CM}_{0.5} \mathrm{P}_{3}(15 \mathrm{~K}), \mathrm{CM}_{0.5} \mathrm{P}_{0}(15 \mathrm{~K}), \mathrm{CM}_{0.25} \mathrm{P}_{3}(15 \mathrm{~K}), \mathrm{CM}_{0.5} \mathrm{P}_{3}(25 \mathrm{~K})$;

c : EPR spectra, parallel mode, $\mathrm{CM}_{0.5} \mathrm{P}_{3}(25 \mathrm{~K})$, experimental, simulated.

Figure 8: Raman spectra of the $\mathrm{CM}_{x} \mathrm{P}_{\mathrm{y}}$ samples. a: $\mathrm{CM}_{0} \mathrm{P}_{0}$; b: $\mathrm{CM}_{0} \mathrm{P}_{3} ; \mathrm{c}: \mathrm{CM}_{0.5} \mathrm{P}_{0} ; \mathrm{d}: \mathrm{CM}_{0.5} \mathrm{P}_{3}$. e: $\mathrm{CM}_{1} \mathrm{P}_{0} ; \mathrm{f}: \mathrm{CM}_{1} \mathrm{P}_{3}$.

Figure 9: TGA/SDTA curves of the $\mathrm{CM}_{x} \mathrm{P}_{3}$ samples. a: $\mathrm{MnO}_{2}$ reference sample; b: $\mathrm{CM}_{0} \mathrm{P}_{3}$ sample; $c$ : $\mathrm{CM}_{0.25} \mathrm{P}_{0}, \mathrm{CM}_{0.5} \mathrm{P}_{3}$ and $\mathrm{CM}_{1} \mathrm{P}_{3}$ samples.

Figure 10: Nitrogen adsorption/desorption isotherms and pore size distribution from BJH in insert of the $\mathrm{CM}_{\mathrm{x}} \mathrm{P}_{3}$ samples: a: $\mathrm{CM}_{0.5} \mathrm{P}_{3}$; b: $\mathrm{CM}_{0.5} \mathrm{P}_{3}$-h; c: $\mathrm{CM}_{0.5} \mathrm{P}_{0}$; d: $\mathrm{CM}_{0.5} \mathrm{P}_{1}$.

Figure 11: a: X-ray diffraction patterns of the samples before: $\mathrm{CM}_{0.5} \mathrm{P}_{3}$ and after: $\mathrm{CM}_{0.5} \mathrm{P}_{3} \mathrm{~h}$, hydrothermal treatment; Zoom on the (111) ceria reflexion in insert. b: SEM picture of the $\mathrm{CM}_{0.5} \mathrm{P}_{3 .} \mathrm{h}$ sample. c, d: TEM pictures of the $\mathrm{CM}_{0.5} \mathrm{P}_{3}$.h sample. 
Figure 1
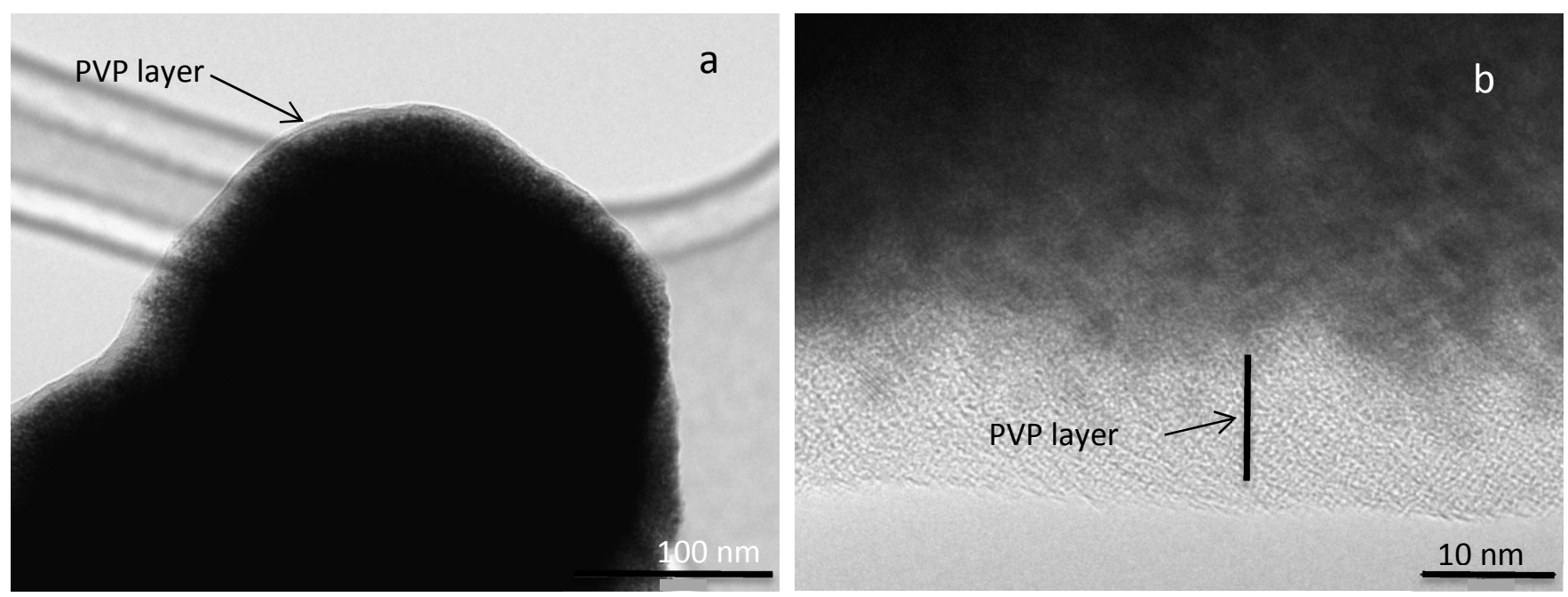
Figure 2

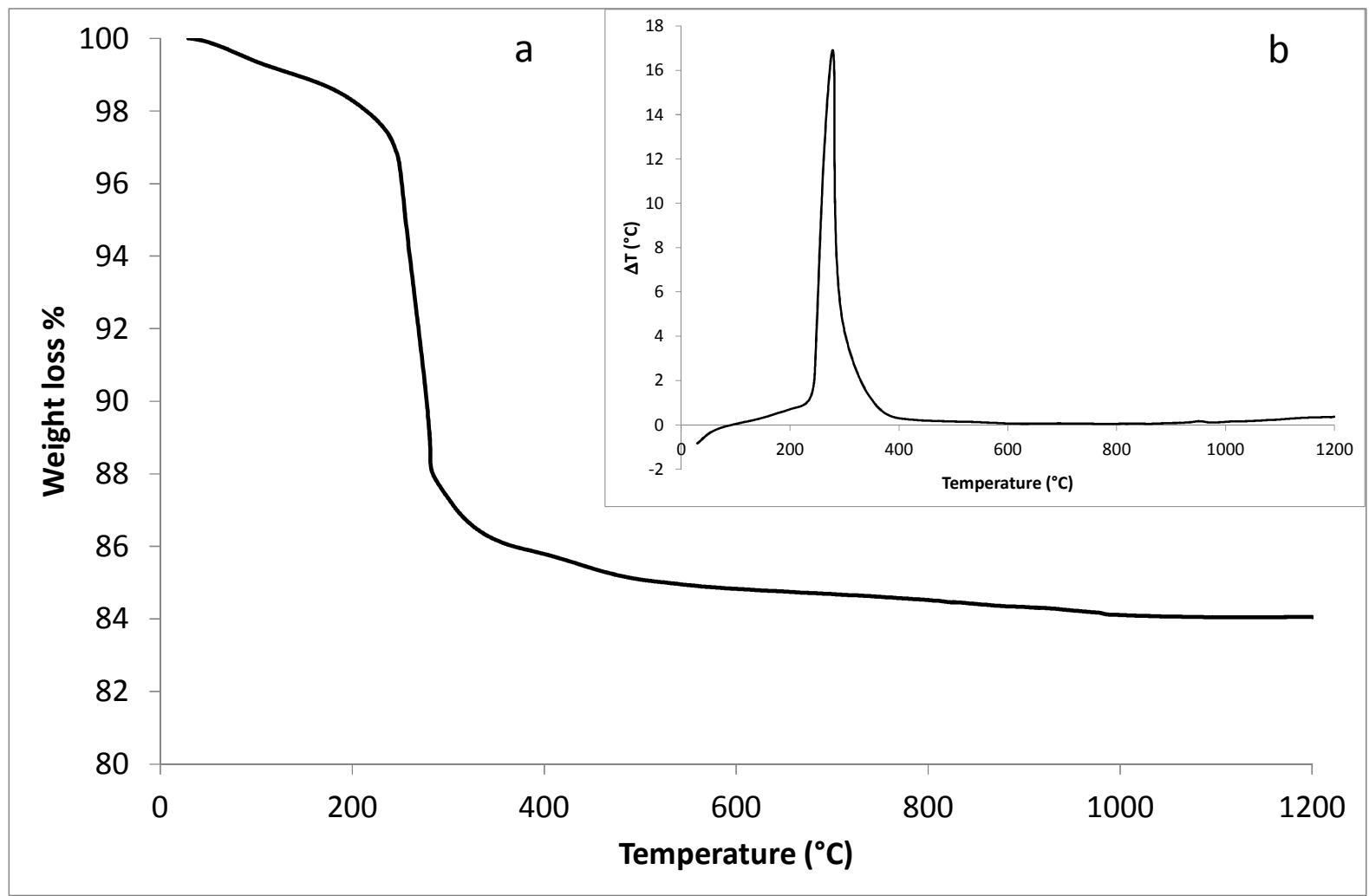


Figure 3
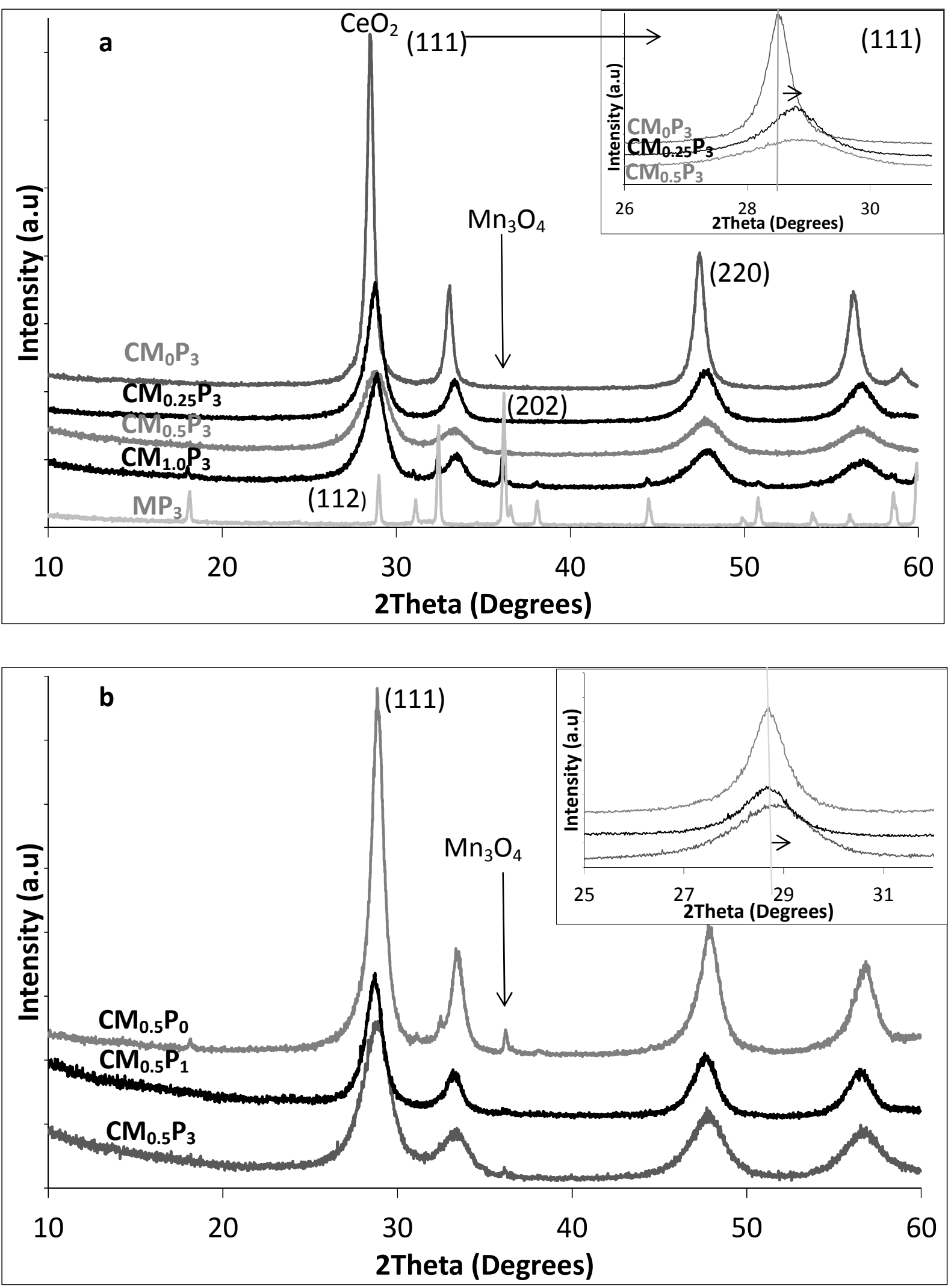
Figure 4

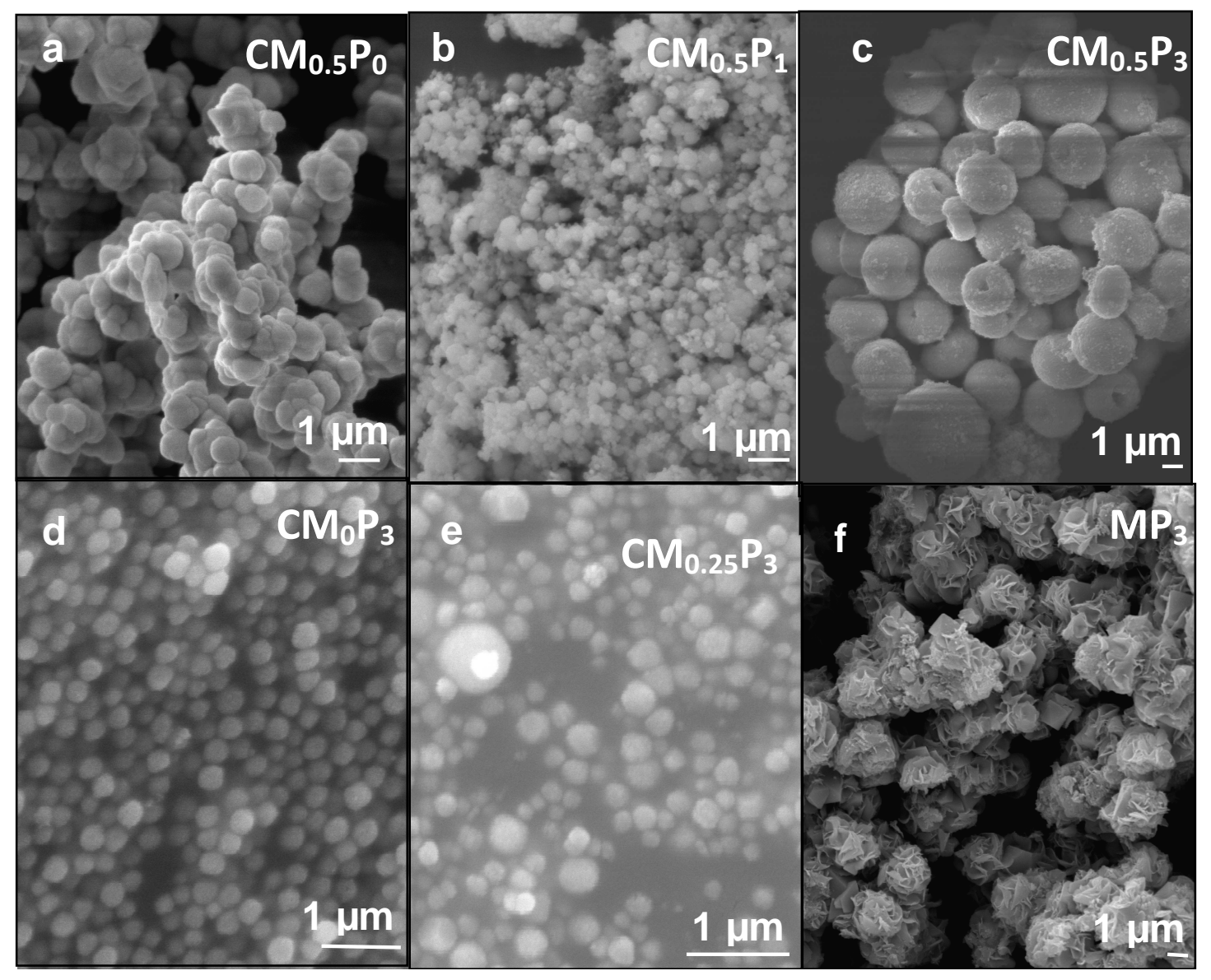


Figure 5

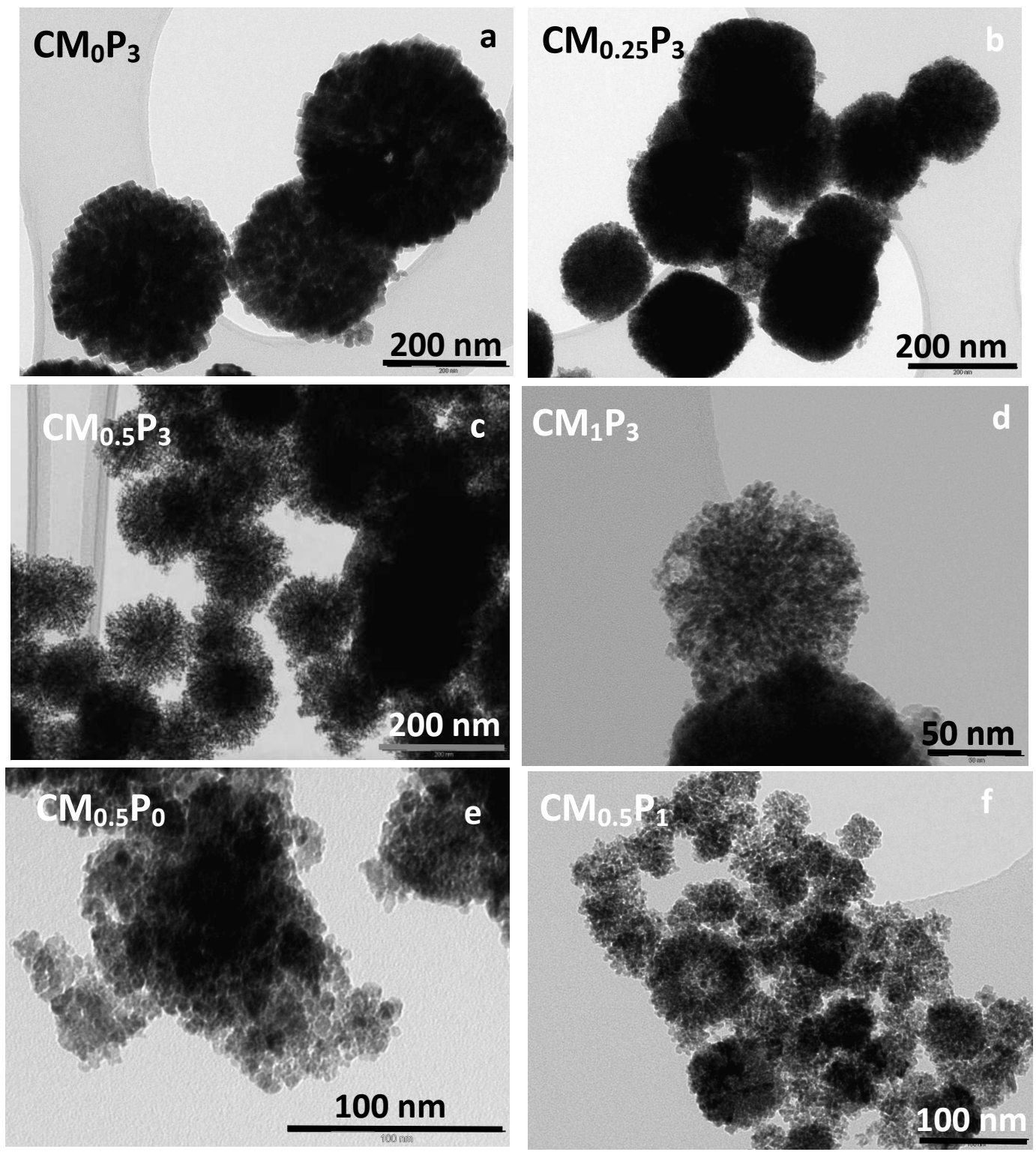


Figure 7
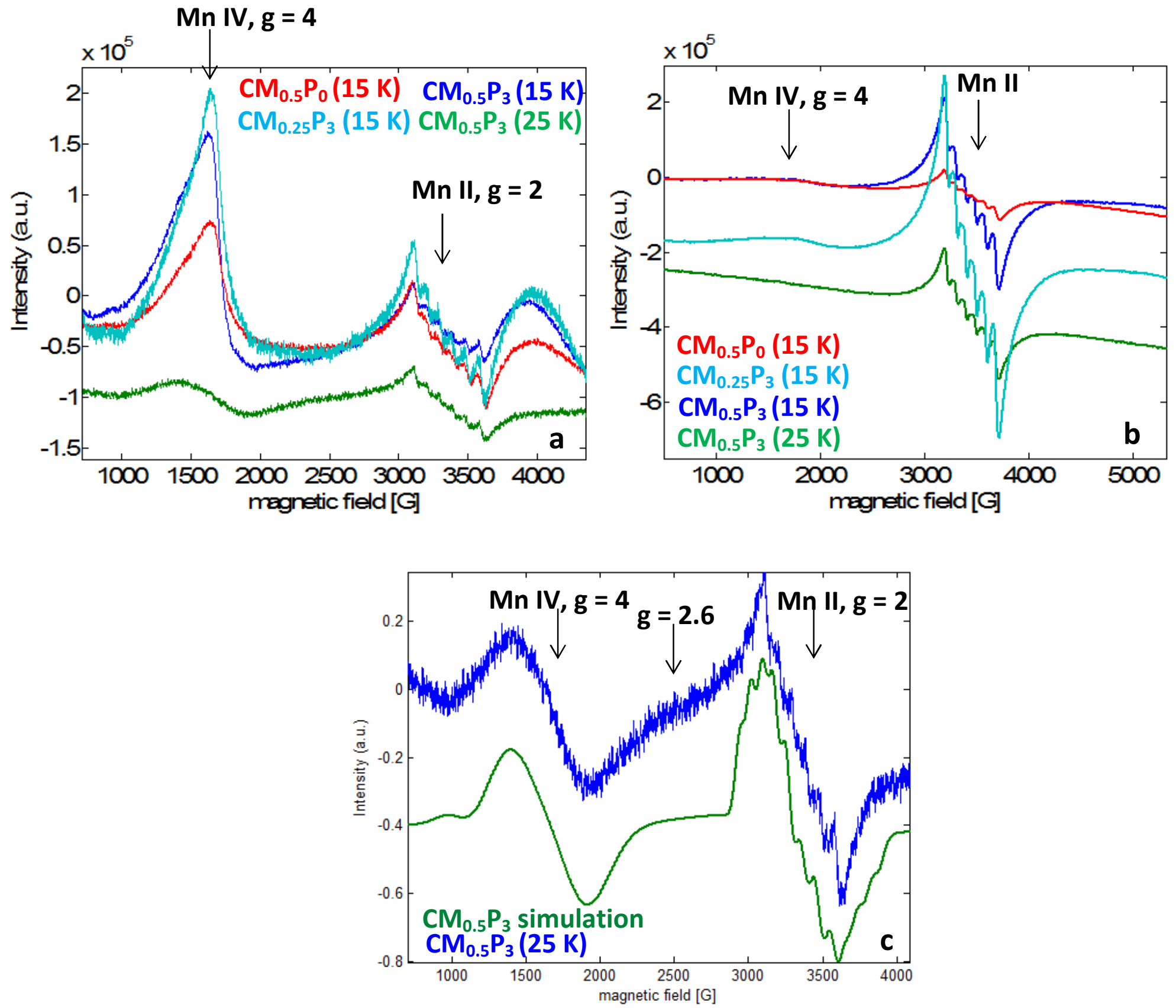
Figure 8
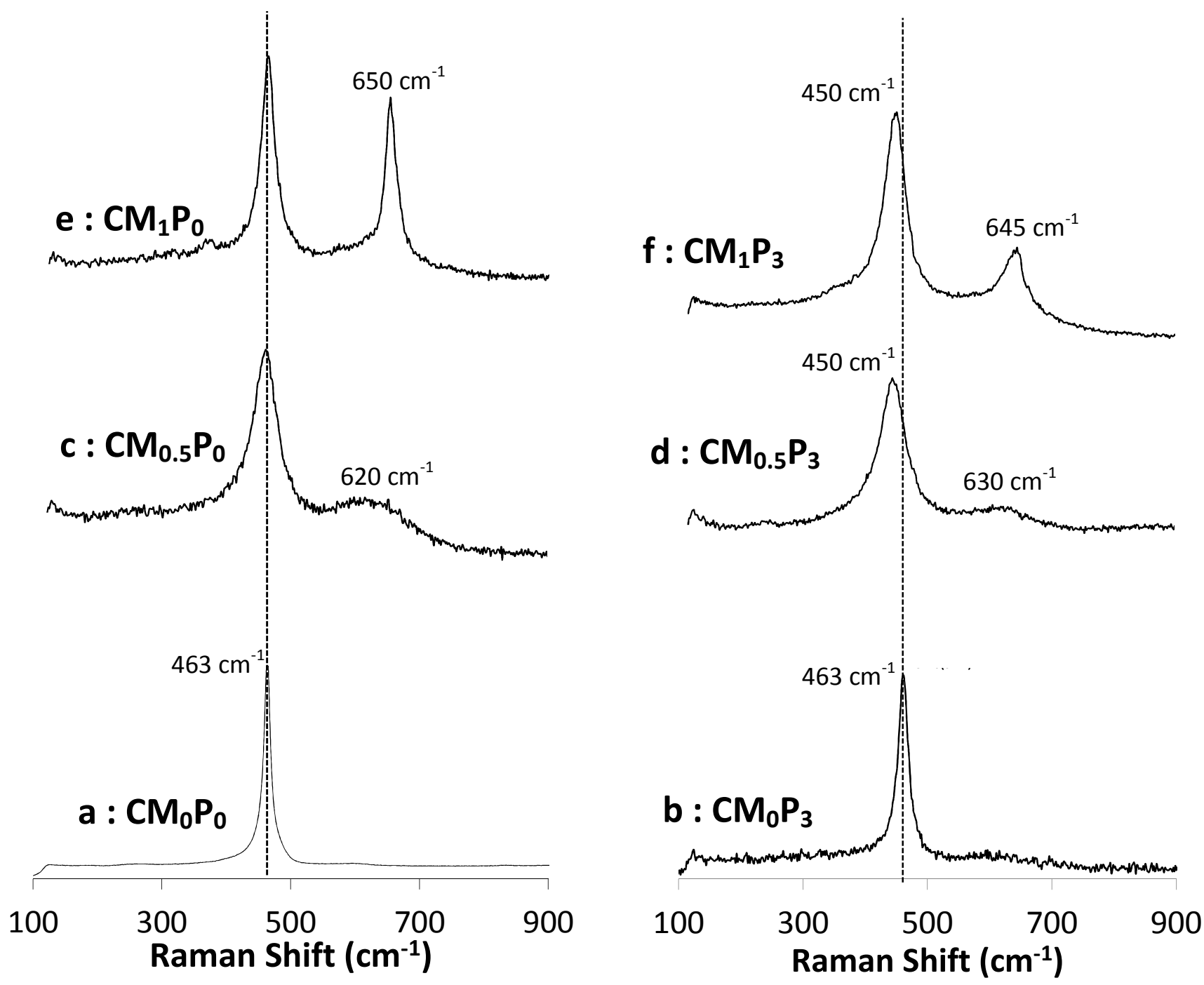


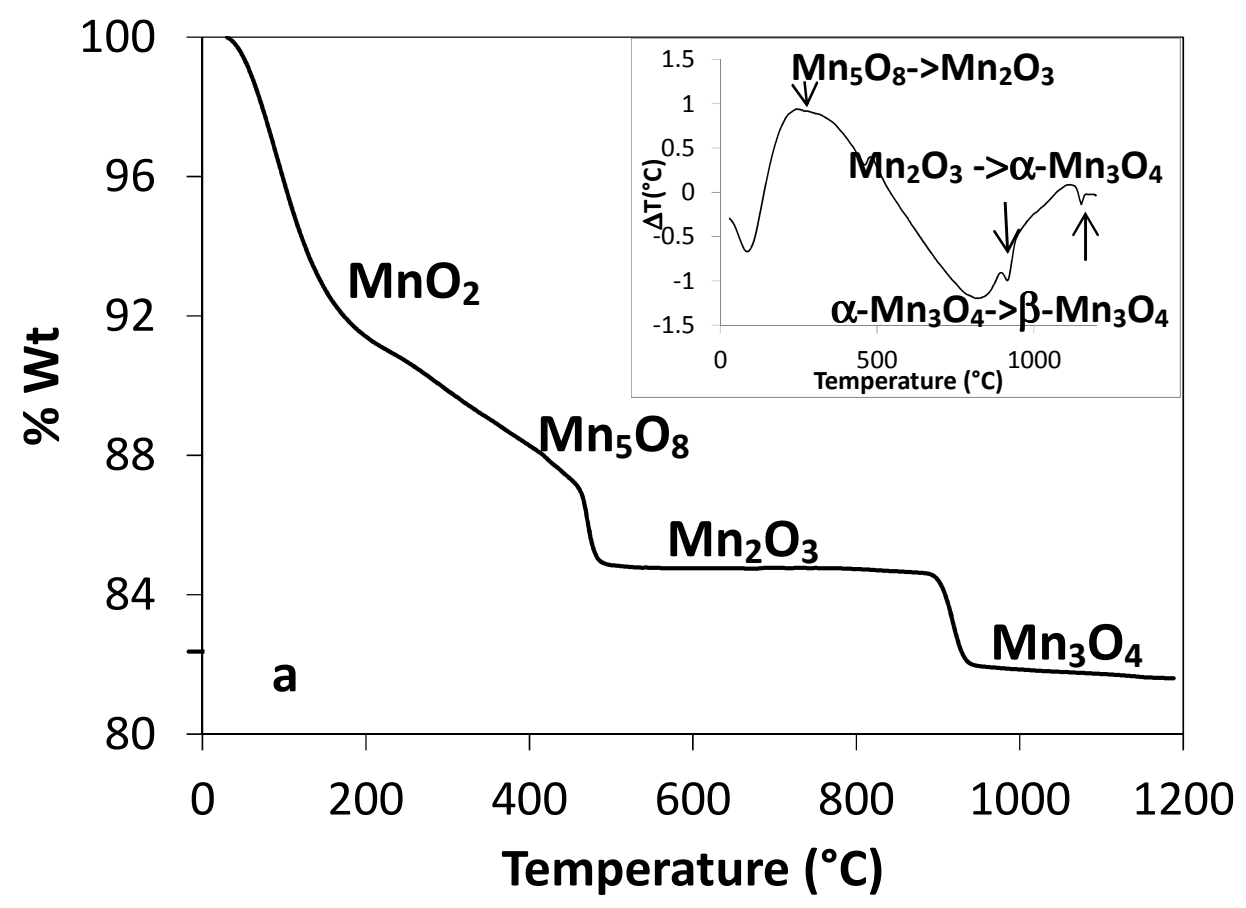

Figure 9
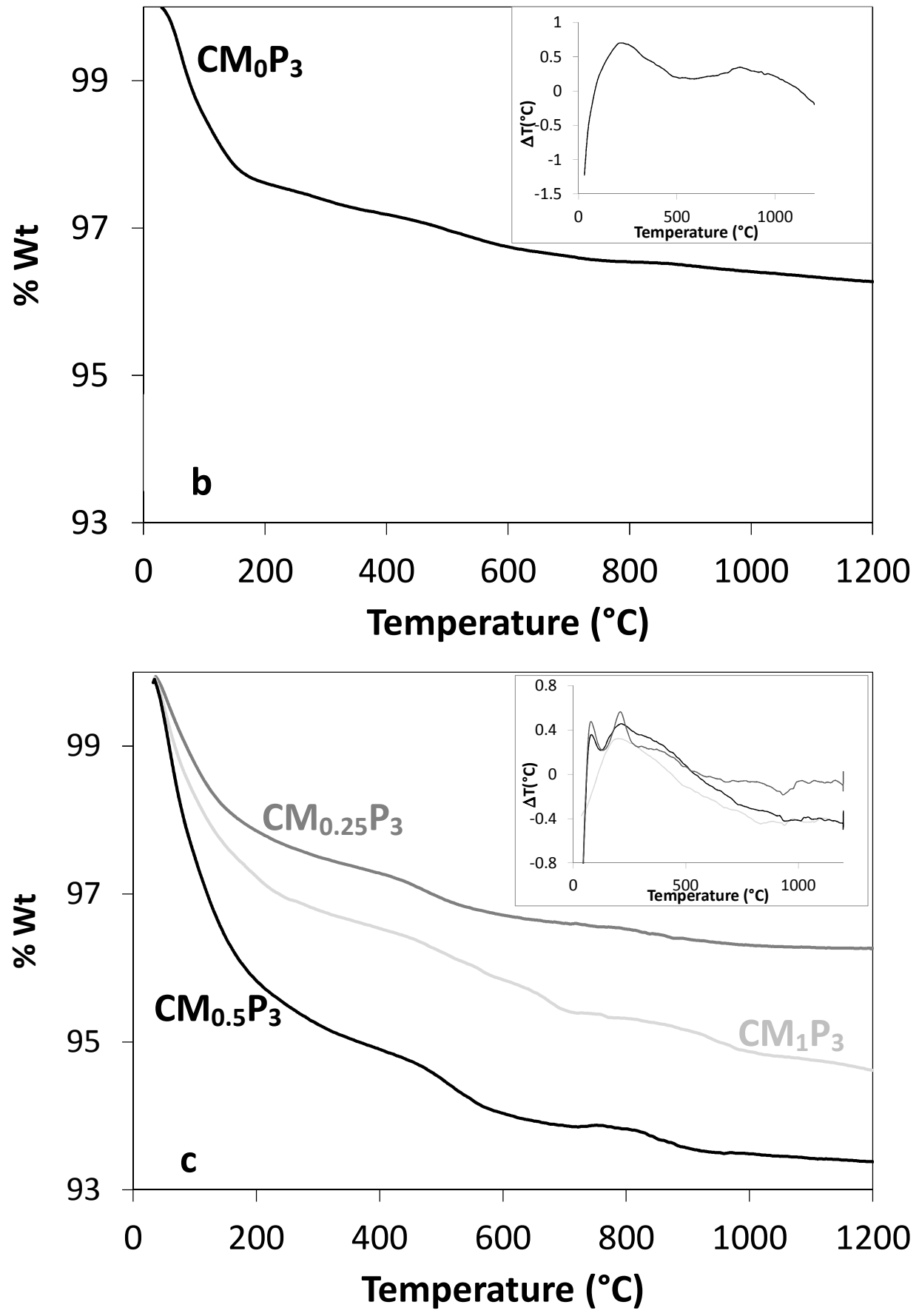
Figure 10
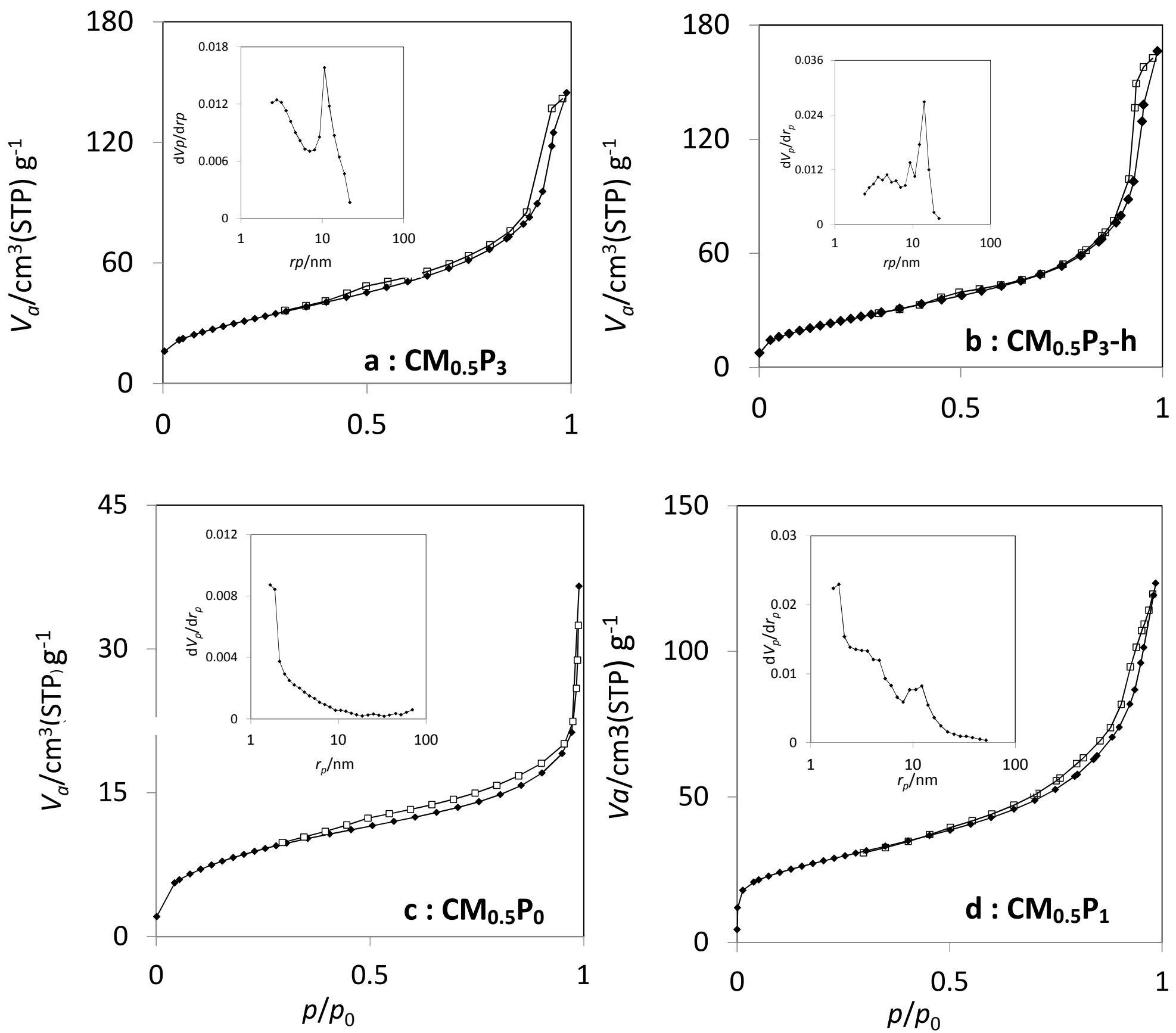
Figure 11
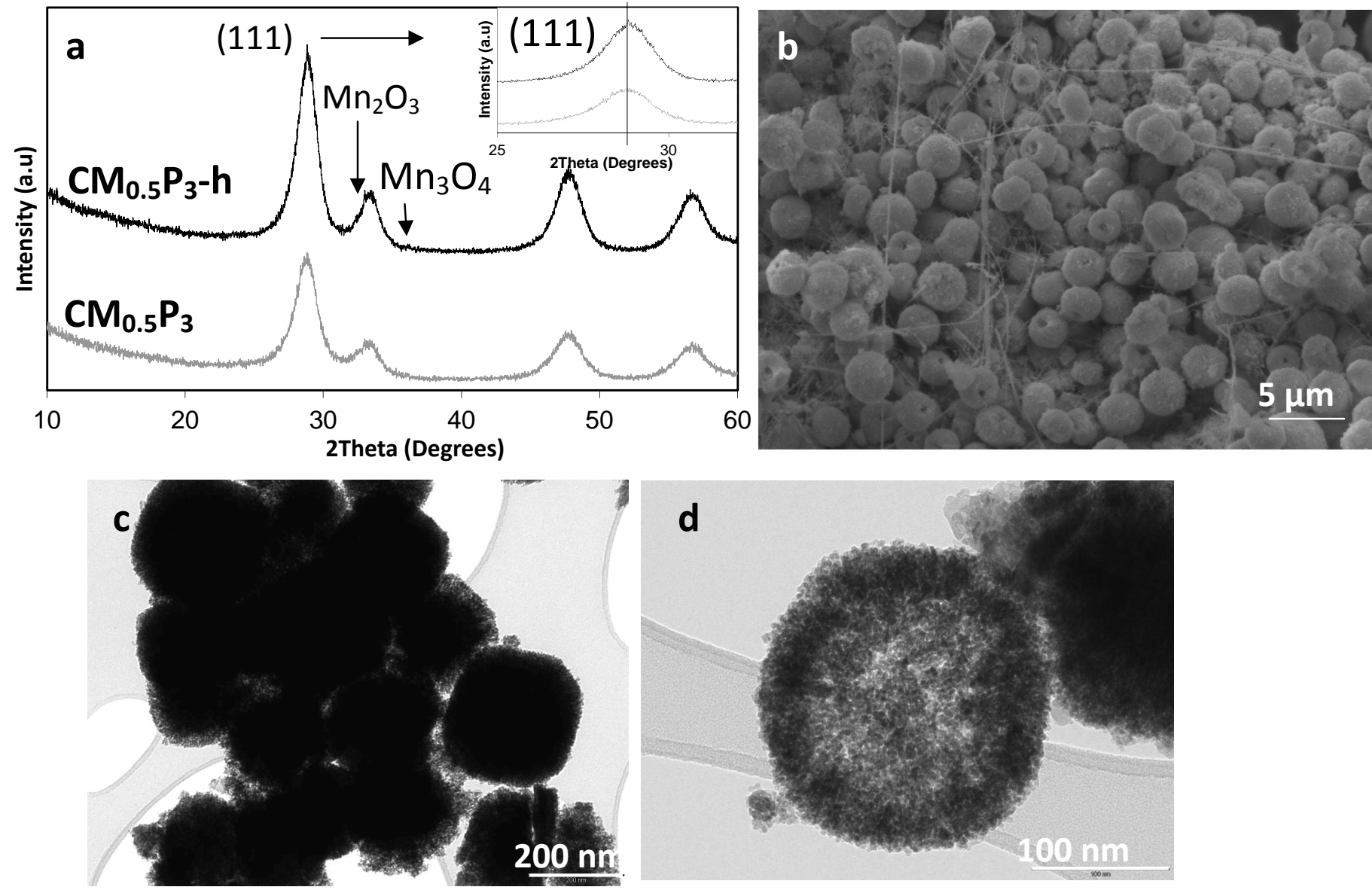